\title{
IKAP
}

JKAP (Jurnal Kebijakan dan Administrasi Publik)

Vol.22 (2), November 2018, 72-82

ISSN 0852-9213 (Print), ISSN 2477-4693 (Online)

Available Online at https://journal.ugm.ac.id/jkap

\section{Managing Government Digital Reputation through Big Data Processing}

\author{
Khoirun Nisa' \\ Ministry of Communications and Information Technology \\ khoi002@kominfo.go.id \\ Effy Zalfiana Rusfian \\ Faculty of Social and Political Studies, Universitas Indonesia \\ effy_rusf@yahoo.co.id \\ Zaenab \\ Faculty of Social and Political Studies, Universitas Indonesia \\ zaenab61@ui.ac.id
}

\begin{abstract}
The objective of this paper is to assess government reputation management performance by leveraging Big Data technology, internet, and public relations capacity, in particular creating credible information for the public. The research used a case study methodology on IndonesiaBaik.id management for the period between 13th September to 13 ${ }^{\text {th }}$ October, 2017. The focus of the research was on the degree to which big data processing influenced communication, public persuasion, and content. Research techniques used to collect data including in-depth interviews, observation, and literature review through elated techniques. Research findings indicate that effective Big Data processing is underpinned by quality data analysis and creative content development skills. This research contributes to knowledge on the application of online reputation management processes for public relations officials and general readers based on the four steps of management process by Cutlip as applied to reputation management analysis using Big Data technology effectiveness. Based on the result of the research the government reputation management practice should also followed by higher competence of the public relation officials especially on the skill of reputation management process and public persuasion skill, thus, the process of creating credible information can be done adequately.
\end{abstract}

Keywords: big data, digital reputation, public relations 


\section{INTRODUCTION}

In the digital age, internet penetration is growing rapidly. According to Balea (2016), global Internet users reached 3.773 billion of the world's total population of 7.476 billion in 2016 (Kemp, 2017). Internet users in Indonesia continue to increase. The Association of Indonesia Internet Service Providers (Asosiasi Penyedia Jasa Internet Indonesia / APJII) noted that while in 1998 Indonesia has 500,000 internet users, in 2016 the number had increased to 132.7 million people out of a total population of 256.2 million inhabitants (APJII, 2017). Meanwhile, the composition of internet users by age showed that in $201618.4 \%$ were in the 10-24 year age group, $24.4 \%$ fell in the 25-34 age group, and $29.2 \%$ were in the 35-44 year age group ( (APJII, 2017). 25.3\% of the internet use is to update the information (APJII, 2017) what do you mean by this statement? In other words, based on the above data, more than $50 \%$ of internet users who happen to be in the productive age bracket use access to internet to meet their information need.

The problem is that internet information is not wholly reliable or at least not all of it is sourced from credible sources. To that end, internet information as a source of information to meet public need, has a credibility problem. In a study by Appelman (2016) that used such indicators as accuracy, authenticity, and reliability to measure credibility of internet messages, showed that not all internet users assess message credibility. The drawback of the study methodology was that it did not take into consideration what participants do when they read online news in their daily lives. The failure of individuals to evaluate information credibility makes them vulnerable to the negative information, which has averse impact on the perception they may have about organization reputation. Doubtless, bad information about an organization undermines its reputation in public eyes, and subsequently tarnish its image.

Thus, information credibility is an issue that organizations should address. The list of internet portals, which the Ministry of Communications and Information Technolo- gy's website named trustpositif.kominfo.go.id and those classified as negative and blocked during 2015 - 2016 period was above 800,000 (Bohang, 2017). To that end, internet websites that contain negative information has become a serious problem that the Ministry of Communications and Information Technology must address, if it is achieve one of the commitments of the Indonesian government to enhance accuracy of information content on internet websites in Indonesia by 2019 or 2020.

There is little doubt then that the deluge of information in the digital age while has many benefits, it also may harbor negative effects, especially it is tarnishes the reputation of the organization. In a Survey concerning hoax 'news' outbreak that became rife in 2017 , which was conducted by Masyarakat Telematika Indonesia (MASTEL) revealed that $91.8 \%$ of hoaxes were about social politics, including the election of regional heads and government (MASTEL, 2017). Moreover, $70.2 \%$ of respondents perceived hoax as an inhibitor to the country's growth and development (MASTEL, 2017), while $60.3 \%$ considered the government to bear full responsibility to stop the spread of hoax in society (MASTEL, 2017). Otherwise, failure to stop hoax, may lead segment of the general public to believe that hoax is credible information, leading to tarnished government reputation and loss of public legitimacy. . In that light, it is an onus on the government to prevent the creation, dissemination and spread of hoax, by among other ways, by producing positive content that counters the negative information, filtering information that is conveyed to the public to remove fake news (hoax), increase public awareness about credible sources of information and how to distinguish between hoax and credible information. This is where the task of public relations comes into play by serving as public liaison between the public and the government.

One of the ways that government disseminates communication is by using the internet. Internet utilization in public relations practice fosters the setting up relationships with the public through a two-way communication process (Holtz, 2002). In 
line with A research by Petrovici (2013) on the impact and efficiency of e-public relations corroborates that finding. Petrovici (2013) argues that online public relations creates a new channel that organizations can use to promote their products or services, thereby enhancing their increase visibility in a virtual environment. Internet technology does not only transform public relations into digital public relations, but also more importantly, monologues into dialogue. By providing a two way communication process, the use of internet by public relations divisions in organizations improves efficiency in communicating with the public, hence strengthens relationships building with the public. To that end, e-public relations has great potential as a communication tool as it is essentially about human relationships.

The increase in the use of internet is not only limited to disseminating data and information but collecting and storing it. Digitization has created opportunities for the collection and dissemination of various large volumes of data, fast (high velocity), as well as storage thanks to technological advances in data storage capacity that have led to dramatic decrease in prices of data storage media. To that end, governments today have the ability to use internet networks to create, store, and disseminate accurate, original, and reliable data. This is what is today being referred to as Big Data. Presidential Instruction Number 9 Year 2015 entrusts the Ministry of Communications and Information Technology to serve as the public relations coordinator of the Indonesian government public relations. Such capacity empowers the Ministry of Communications and Information Technology to coordinate efforts and programs undertaken by the Indonesian government to digitize government functions, through Nawacita Digital Library (NCDL). The program serves as an integrated database that collects and stores information from other ministries / agencies / local governments as well as from within the Ministry of Communications and Information Technology itself to support the implementation of information dissemination. Nawacita Digital Library (NCDL) entails the development and management of an integrated data bank in the form of a digital library that contains specific information drawn from communications, Information, and public Relations institutions in 34 ministries and 129 non-ministry agencies. In addition, the project undertakes data analysis, and visualization of data, to enhance the ease of use in the policy making process and accessible to other parties that may have interest in monitoring the conduct of government functions (Directorate General of Public Information and Communications, 2017).

The data bank used in developing the NCDL program is a website-based public communication information system (Sistem Informasi dan Komunikasi Publik/SIKP), containing thousands of data points collected from accurate, original, and reliable information sources. The data in the SIKP system is drawn from (reports produced by public relations personnel or officials charged with managing information and documentation in various ministries and non-ministries. Thus, this tranche of data, can be analyzed and visualized in such manner that can leverage government reputation. The objective of this research is to assess the performance of government on utilizing Big Data that is available to execute reputation management and in improving public service delivery.

Data can be a source of economic value for an organization. Schönberger (2013) defines Big Data as the ability of people to utilize information in new ways to generate useful insights or goods and services with significant value. Schönberger (2013) further elaborates that Big Data is all about seeing and understanding relationships within and between existing information This is because, according to Schönberger (2013), information evolves four times faster than economics, which is largely thanks to the exponential increase in the processing speed of computer processing capacity that is today nine times faster. The increase in data created at rapid speeds, has led to the problem of excessive information or information overload.

To that end, the importance of this research lies in its contribution to the extent to which the government is making use of the vast volumes of data that is collected from various government offices to manage its reputation and legitimacy. This research uses the stages of the reputation management 
process as the first framework and completed by the communication model that occurs in a new way of online reputation management between government and society. The utilization of new ways of managing government online reputation management in Indonesia is only found in IndonesiaBaik.id. Specifically, research results also provide an important source of reference for public relations officers in applying online reputation management processes. Meanwhile, for general readers, this research provides a detailed elucidation of the four steps of management process based on Big Data technology, which were developed by Cutlip in executing public reputation management.

IPR (Institute of Public Relations) in Theaker (2004) defines public relations as a science that tackles efforts to create and preserve the reputation of the organization by generating understanding and support for its activities and functions. Understanding and support of the organization is achieved through the delivery of information bolsters organization reputation. Government public relations officers have bounden duty to explain to the public about the impact that government programs and policies have on their lives (Subiakto, 2014). Government public relations officers are like journalists who collect information and then disseminate it to the public. Moreover, government public relations officers serve as government representatives who explain the benefits of actions that the government take, as well as rectify information that is not accurate or ambiguous, hence liable to multiple interpretations. In a research by Prindle (2011) on the role of public relations in brand messaging, it was revealed that public relations function plays an important role in maintaining trust and authenticity of the branding message, especially through storytelling on social media. It is such a role that has catapulted public relations efforts to become vanguards in organization efforts to preserve the reputation of the organization. Top achieve that feat, public relations must produce, provides good and credible information to the public which helps to strength public trust in the government. Credible information in part depends on the source of the data that is processed t produce the information. Credible information is accurate, original, and sourced from reliable sources..

Reputation according to Smith (2002) is based on words and actions, planned and unplanned by the organization. Words and deeds coming from the organization can be in verbal, visual forms or behavioral messages. Reputation is a perception that can differ from one individual to another and vary over time. Indeed, reputation is an outcome of a conscious organizational effort to influence the way people perceive it. To that end, reputation, according to Fombrun (1996) influences advantages that an organization has or is perceived to have. Reputation generates advantages for the organization through enhanced public interest, investors, and of employee performance improvement.

With regards to reputation in the public and private sectors, Luoma-aho and Canel (2016) contends that reputation approach in the public sector has more complexity than that in the private sector. This is attributable to among other factors, the fact that the government as a public sector organization has complex goals, needs, public, definitions, and resources. Therefore, measuring the quality of public sector organizations is based on the performance in the delivery of public services, the quality of organizational support and focus put in fulfilling public needs. Some previous research has examined the complex dynamics of indirect causal relationships between the achievements of public organizations, communication performance, citizen satisfaction and trust. Canel and Sanders (2012) conducts research on the role that public relations function plays in informing and persuading the public through government communications. The importance of the exercise lies equipping the government with ways to build public trust in the relationship between the government and the governed, through the concept of government reputation.

There is a lot of research in previous literature that deals with on the conduct of government communication of relevant information to stakeholders by government organizations as part and parcel of in delivering public services in general and in influencing public perception about government 
reputation in particular. Fombrun in Theaker (2004) defines reputation management as a systematic process that relates to efforts organizations take to shape the way there are perceived and evaluated. According to Smith (2002), the goal of reputation management is to enhance the organization's reputation in terms of prestige, employee image and the strength of the organization in society. Research by Phillips (2008) on public relations and reputation shows that through branding, public relations influences the reputation of the organization. . Reputation management involves understanding the reputation of the organization and taking actions that have positive effects on its reputation. Therefore, reputation evolves through organization communications over time, which thus, is strongly influenced by intrinsic elements of public relations.

According to Cutlip (2009), reputation management can be explained in four problem-solving steps: 1.) interpret problems and opportunities; 2.) planning and programming; 3.) to take action and communicate; and 4.) evaluate the program. In the first step, public relations officers conduct investigation and conduct monitoring of knowledge, opinions, attitudes, and behavior of the parties that are influenced by actions and policies of the organization.. Secondly, collection of information and gauging the implications on decisions made concerning public programs, objectives, strategies and actions, communications, tactics, and targets. This step focuses on what the organization needs to do based on the information that is already collected. Thirdly, implementing action and communication program after consummating planning the program in line with program objectives. This step relates to adoption of planning of program implementation, time, and place. Finally, conducting program preparation assessment, implementation, and program outcomes. In this case, objectives of the program must adjust to feedback on program implementation performance.

Theaker (2004), provides a framework that has been used by previous researchers to conduct research on reputation management during the process of disseminating information by public relations offices. The pub- lic relations model developed by Grunig and Hunt is based on phases that include 1) Press agency or publicity model; 2) Public information model; 3) Two-way asymmetric model; and 4) The two-way symmetrical model. The first model emphasizes the importance of individual or organizational publicity through the media in influencing organizational reputation. Public relations emphasizes to the role that the attention paid to clients of the organization through the media. The second model aims to provide and disseminate accurate information to the public. Public relations responds to the public whenever the latter has penchant need for important information. The third model illustrates persuasive communication that demands public relations to understand attitudes and behavior of the targeted public. Public relations officers deliver messages based on research results and scientific strategies, to persuade or even manipulate the public for purposes of serving interests of the organization. The last model requires the existence of dialogue between public relations officers and the public, a process that creates opportunities for exchange of ideas. In this model, activities of public relations officers are not only based on research, but also combine such with communication techniques that foster improved public understanding public about government issues and policies.

Big Data can be described as something that can generate new insights or create new value in ways that change markets, organizations, and relationships between citizens on other stakeholders on one hand, and the state, on the other. Its revolution revolves around the value attached to data itself, and how it is put to use, rather than as a machine revolution that computes the data. The data revolution and increasing use of value derived from data is evident in research conducted by Mediaswati and Sidik (2013). The research discusses management, distribution, and utilizing data to filling employees' reports based on the website. Mediaswati and Sidik (2013) finds that factors that influence acceptance of employees' data collection technology include leaders' thinking, commitment, data management system security, availability of clear legal basis for the technology adoption and $\mathrm{s}$ 
availability of sufficient human resource capacity. Meanwhile, as regards the challenges faced in adopting employees' report filling web- based technology, Mediaswati and Sidik (2013) identified absence of sufficient human resources unavailability of supportive technological infrastructure. To strengthen web based employee report filling technology in organizations, Mediaswati and Sidik (2013) recommend the implementation of personal data management policy, improvement in the employee division of labor, conducting employee training in the use of the related applications, undertaking good technological infrastructure planning, and improving agency performance.

The ability and capacity of the government to provide information to serve public interests is strongly linked to the technology used to collect such data. Thus, collecting quality internet data, hinges on government performance in development and managing its websites. The provision of information through website enhances information disclosure, which the government can put to use in various areas ranging from procurement of goods and services, natural disaster management, improvement in education service delivery. A research by Aprizal and Purba (2013) on the implementation of EProcurement system in Pangkalpinang city government, showed that one of the outcomes was marked improvement in public access to information on o procurement of government goods and services and higher engagement in the procurement process. Meanwhile, a research by Wahyuni and Indarwanto (2008) showed that a website plays an important role in providing accurate and valid government data and information. Thus, the government can make of the website as as a channel to deliver digital government services to provide data services and information related to public needs . Concretely, Wahyuni (2008) gives examples of various digital government services already using website services to provide government services such as natural disaster handling site, under the management of Yogyakarta Provincial Government (DIY), other websites that belong to Implementation Unit of Bantul Regency and Sleman Regency Government. In addition, Yogyakarta provincial government (DIY), also manages a website which it uses to promote developments in the through information portals on tourism, improving the quality of education through a number of learning portals. It is thus, evident, digitalization can enhance the ability of the government to provide public services to meet various public information needs.

Research by Llorente's (2016) on Big Data, online reputation, and knowledge management in online higher education, showed that distance learning applications can facilitate teacher-student learning and interaction. The application collects and updates data during the learning process, as well as increases interaction, hence monitoring in the learning process easier. That way educational organizations are equipped with better ways on identifying reduced student attendance and drop outs. Moreover, the deployment of the application, by increasing interaction, strengthened reputation of the educational organizations thanks to enhanced transparency, trust, and the digital identity of a school. Nonetheless, in another study on Big Data, in public education affairs (Mergel, 2016), showed that s getting the benefits from Big Data requires changes in government information management skills.

The government can make use of SIKP Big Data (to improve government reputation. This is because SIKP data is accurate, original, and reliable. Moreover, the data is in a ready-to process format by government public relations officials into credible information, which can then be disseminated to social media various campaigns to support government policies and programs. One of the functions of government public relations divisions, is to provide public information with the purpose of enhancing public understanding about government programs and to that end, the quality of government communication strongly influences the impact it makes on the perception of the public about its reputation.

\section{METHODS}

The research uses case study approach. The choice of research design because it provides an opportunity to the researcher to conduct a detailed contextual 
Khoirun Nisa', Effy Zalfiana Rusfian, Zaenab - Managing Government Digital Reputation....

analysis of government digital reputation management through Big Data processing at IndonesiaBaik.id case. The research draws on evidence that was obtained largely from in-depth interviews, observation, and literature review. In-depth interviews were conducted with one staff member and one supervisor relating to information on Big Data processing activity. Informants were chosen based on purposive sampling technique. A staff member was selected as an informant based on the criteria that he or she was civil servant whose duties and functions were in the implementation of the program as well as head of public information project in the Government of IndonesiaBaik.id website. Meanwhile, was based on the criteria that included being a leader of the IndonesiaBaik.id government program plays a role as responsible for the implementation of policies, supervision, and evaluation of public information and data that is conduct of government activities. The conduct of observation was aimed at making onsite first hand observation of the Big Data processing activities as part of the information processing, analysis and visualization. Review of previous literature was made in order to obtain supplementary information about the output of Big Data processing exercise as contained in three official documents of the Subdirectorate of Information Processing. The period of observation was September 25th, 2017 to October 9th, 2017. Selection of documents to analyze was based on IndonesiaBaik.id data that related to legal protection (Directorate General of Public Information and Communications, 2017). Nonetheless, evaluation of the performance of the extent to which the government had fulfilled its goals with respect to processing and disseminating government information was limited to First Semester Report of the Subdirectorate of Information Processing (Laporan Semester 1 Subdirektorat Pengolahan Informasi) (Sub-directorate of Information Processing, Directorate of Information Processing and Provision, Directorate General of Public Information and Communications, 2017).

\section{FINDINGS AND DISCUSSION}

The leveraging of Big Data processing by the government in managing its reputation follows four phases as elucidated by Cutlip, inter alia, interpreting the problem and opportunity, which involves investigating merging issues in Indonesia; planning and programming that focuses on selecting the main issue, which the government wants to handle or solve; dealing with the Big Data delving process that entails getting information related to the selected issue, conducting data processing, and dissemination of the information. This research focuses on the Big Data processing phase of the digital reputation process.. The phase involves taking action and communicating the results obtained from data processing. To that end, the phase encompasses content making, and communicating the results through disseminating the information, followed by evaluation of the process based on performance of content measurements.

The role that public relations plays in the process entails explaining to the public about the impact of government programs and policies, benefits of government strategy, and clarifying and rectifying inaccurate information to avoid ambiguity and multiple interpretation with respect to the content of branding messaging as featured on IndonesiaBaik.id. Government data that is drawn from SIKP are accurate, original, and reliable, a, managed formally under the e tagline, IndonesiaBaik.id, and attracts digital native public, especially adolescents (between 18 and 34 years old). Considering the fact that characteristics of the target audience include art, photo and video sharing, photo and video services, social and politics, graphic content, data, and design, messages that are designed and disseminated by IndonesiaBaik.id are in infographics, motion graphics, and articles. . The production of contents on IndonesiaBaik.id follow norms, standards, procedures, and criteria that are required to produce good quality content.

Content on IndonesiaBaik.id takes two general forms, that is, government public relations and campaign (Nisa, 2018). Nonetheless, of the two forms of content on IndonesiaBaik.id, PR is the most predominant, and comprise "Government Programs and daily Issues. Contents on government 
programs consists of government development achievements various sectors. Meanwhile, content of daily issues comprises background information of issues that are attracting public attention and concern at the time as reflected in issues that in mass media. Campaign content on IndonesiaBaik.id contains interesting information relating to both the government and non-government issues that is consuming public attention as reflected in IndonensiaBaik.id social media accounts. The content of campaigns specifically, published through the focus on "About Indonesia" and "Education and Information of Public Services" themes. The "About Indonesia" theme consists of various interesting facts, ranging from various exciting and unique things to local Indonesian wisdom. Meanwhile, "Public Education and Information Services" delivers a variety of tips and related information on public services. Essentially, thus, content on, IndonesiaBaik.id, has employs four pillars of information to provide information that meets public needs, while at the same time building and preserving government reputation and upholding the image of the state in public eyes. The four phases are described in details in the following section.

\section{Interpret problems and opportunities}

IndonesiaBaik.id program has nine Civil Servants and 15 (fifteen) contract workers who are charged with handling the program. The team conducts weekly meetings to identify and assess emerging issues in Indonesia. Nonetheless, on several occasions, the team has to investigate emerging issues in the country that the central government officials consider important. To that end, IndonesiaBaik.id employees are expected to be ready to investigate and upload priority issues that are based on decisions of the central government. Such issues include news concerning crises or general issues that are hot topics, which the public needs to know as soon as possible. Besides, IndonesiaBaik.id employees are required to collaborate with any organization in creating and disseminating content as long as such contents are in line with goals.

\section{Planning and programming}

Weekly meetings do not only serve as venues to analyze issues but also conduct planning of the issues to be raised or uploaded on every weekday. The selection of the main issues is based on the government agenda of priority programs, namely political (legal, human rights), strategic (politics, law, security), economy, maritime and resources, and human and cultural development related issues. Inevitably, the four pillars that underpin content have implications for the issues that the team creates and publishes every day.

\section{Take action and communicate}

The plan to publicize or disseminate issues, which begins with carrying out an investigation of the issue by IndonesiaBaik.id team. The team digs up SIKP government data and official news channel, which is managed by the institution. Results of the investigation exercise are used to develop a storyboard, which is subsequently sent to the visualization section to transform it into infographics and motion graphics. Visualization types used are influenced by the target audience as well as guidelines on public content tailored for public consumption. Subsequently, results from the visualization section are sent to the content authorization unit for quality checks before they are returned to the production section for final checks, prior to submission to the content uploading division. The latter division uploads the info graphs and motion graphs to official social media accounts.

IndonesiaBaik.id id utilizes the official website and media social accounts to handle contents. Nonetheless, website serves as the main data collection platform while social media accounts are the used to disseminate the information. To ensure that then message reach as many people as possible, IndonesiaBaik.id id uses Facebook, Twitter, Instagram, and YouTube as information dissemination media, as well as a vital source of feedback from the public.

\section{Program evaluation}

To gauge the performance of the website with respect to data content, IndonesiaBaik.id uses the quantity of content produced and uploaded. Meanwhile, IndonesiaBaik.id uses various Key Performance in- 
Khoirun Nisa', Effy Zalfiana Rusfian, Zaenab - Managing Government Digital Reputation....

dicators (KPIs) to gauge social media the performance on information dissemination. KPIs used include copywriting, posting, reach, page likes, and others. Performance measurements and content statistics serve as inputs into social media analysis process that employs Big Data search engine optimizer (SEO) technology to generate results that are later used to inform decisionmaking related to program sustainability.

To that end, by making use of Big Data technology, public relations officers, through IndonesiaBaik.id are able to enhance their role as digital reputation managers right from the beginning (issue identification and interpretation) to feedback into policy making process.

Based on findings of this study, one of the insights is that the digital reputation management process based on Big Data collection, analysis and dissemination, demands the availability of employees with competence in public relations capability. Such capabilities include being knowledgeable about all key current issues in Indonesia, especially those that relate to the function of the government and public service delivery; acumen to conduct research related such issues raised; creative skills such as storyboard making, infographics and motion graphics making; creativity in using SEO strategies to optimize information dissemination; and ability to read and interpret data analysis and statistics that Bog Data technology generate to develop reports and draw policy implicates and recommendations. Equally important is the finding that improving direct communication between the government and the public is imperative for better reputation management. Consequently, to be a vital source of policy socialization and public awareness, the dissemination of contents of IndonesiaBaik.id should not only be interesting in terms of appearance, but also persuasive and easy to understand by the audience. Moreover, there is need for social media division to acknowledge and quickly respond to public comments that take forms such as likes, love, delivered through emojis and texts on IndonesiaBaik.id social media accounts.. Since the public plays an important role in in the dissemination of information by sharing the content on their personal social media accounts, IndonesiaBaik.id involves the public in the program beyond the virtual world (social media games, online giveaway) to sponsoring internship programs and strengthening collaboration with in communities in advanced education institutions. In addition IndonesiaBaik.id conducts research and interactive communication with various stakeholders to address emerging and current issues. It is thus apparent that in conducting digital reputation management, the government uses as a two-way symmetrical communication model that involves providers and target audience in an interactive manner which enhances its persuasive ability. Besides, to ensure that issues that are disseminated to the public are based on sound facts and evidence, the government, through IndonesiaBaik.id conducts background research on content-related issues.

The Indonesian government through IndonesiaBaik.id has been able to leverage internet as a media to collect and disseminate policy related data that is later analyzed to create information that is disseminated to the public to raise awareness about current issues, clarify misinformation concerning public programs and policies, and as a vital way to improve public perception about the government (reputation management). The two way, interactive communication that internet makes possible, ensures that the government leverages its access to Big Data collected from various ministries and nonministerial institutions for analysis to provide updated information about government stand and trajectory with regards to key programs and policies, including issues that are consuming public attention on social media and other channels.

\section{CONCLUSION}

The government runs the role of public relations related to digital reputation management through the help of Big Data technology. The collection of accurate, authentic, and reliable data on the data bank system is the source of the research. Search engine optimization is also used to disseminate reputation. Performance analysis technology and social media statistics are used to measure the effectiveness of reputation-related 
content. Big Data processing on IndonesiaBaik.id brand messaging requires employees to have certain capabilities. Furthermore, internet technology and especially social media facilitate digital reputation management to launch two-way symmetrical communication model.

The main findings of this research are the need for public relations officers to use Big Data technology balanced with the knowledge of how to use it and to process it to be public information. Public relations must have investigation and monitoring skills when looking at organization issues to be able to choose important issues. Public relations also must have planning and programming skills to create and disseminate content. On the other hand, planned strategy to create and disseminated content needs good implementation and good communication from public relations. Therefore, these activities need Big Data technology, information processing technology, and human resources that can operate the technology. It is also important to know that good program implementation must be completed by an evaluation of the program to know the results of the program. Quantity and quality information, outreach of content dissemination, and citizen feedback are needed to adjust the goal of the program.

This research also has some drawback; therefore, it is necessary to refine the next research. Based on the case study research method used in IndonesiaBaik.id, the results of this research may not be the same if it is applied to another research object. However, this research has a theoretical framework that is related to reputation management theory that can be applied in further research related to the use of Big Data technology on reputation management. The results of this research show that public relations officers can take advantage of technological sophistication to manage reputation.

The results of this research can be used as a reference for applying digital reputation management through Big Data processing by local governments or other public relations institution. Local governments can collect data from various units through a coordinated mechanism of public relations. Local governments can use internet technol- ogy to disseminate government-related information. Big Data technology that is free certainly makes it possible for local governments to adjust their digital reputation management budget easier. Internet technology mediates the relationship between the government and the public allowing them to interact directly. Local governments seeking to build relationships with the public interactively should use this opportunity.

\section{REFERENCES}

APJII. (2017, January 31). Infografis Penetrasi dan Perilaku Pengguna Internet Indonesia Survey 2016. Retrieved from https://www.apjii.or.id

Appelman, A., \& Sundar, S. S. (2016). Measuring Message Credibility: Construction and Validation of an Exclusive Scale. Journalism \& Mass Communication Quarterly, 93(1), 59 -79. doi:10.1177/1077699015606057

Aprizal, \& Purba, J. R. (2013). Akuntabilitas Pelayanan Publik Dalam Pelaksanaan E-Procurement di Kota Pangkalpinang. Jurnal Kebijakan \& Administrasi Publik, 17(1), 15-28.

Balea, J. (2016, April 15). The Latest Stats in Web and Mobile in Indonesia (Infographic). Retrieved from https:// www.techinasia.com/indonesia-webmobile-statistics-we-are-social/amp/

Bohang, F. K. (2017, August 28). Kominfo Targetkan 2019 Konten Positif Dominasi Internet Indonesia. Retrieved from Kompas: http:// tekno.kompas.com/ $\mathrm{read} / 2017 / 08 / 28 / 13294697 /$ kominfotargetkan-2019-konten-positifdominasi-internet-indonesia

Canel, M. J., \& Sanders, K. (2012). Government Communication: An Emerging Field in Political Communication Research. In H. Semetko, M. Scammel, \& C. E. Carroll (Ed.). The Sage Handbook of Political Communication (2 ed., pp. 85-96). London: Sage.

Cutlip, S. (2009). Effective Public Relations. (T. Bowo, Trans.) Jakarta: Kencana.

Directorate General of Public Information and Communications. (2017). Government Public Relations Terms of 
Khoirun Nisa', Effy Zalfiana Rusfian, Zaenab - Managing Government Digital Reputation....

Reference. Jakarta: Ministry of Communications and Information Technology.

Directorate General of Public Information and Communications. (2017). Laporan Ringkas Program Kerja Prioritas Government Public Relations dan Alokasi Anggarannya. Jakarta: Ministry of Communications and Information Technology.

Fombrun, C. (1996). Reputation: Realizing Value from the Corporate Image. Boston: Harvard Business School Press.

Holtz, S. (2002). Public Relations on The Net Winning Strategies to Inform and Influence The Media, The Investment Community, The Government, The Public, and More! (2 ed.). New York: Amacom.

Kemp, S. (2017, January 24). Special Reports Digital in 2017: Global Overview. Retrieved from https:// wearesocial.com/special-reports/ digital-in-2017-global-overview

Llorente, C. L. (2016). Big Data, Online Reputation and Knowledge Management in Higher Education Online. Social Sciences, 5((6-1)), 1-6. doi:10.11648/j.ss.s.2016050601.11

Luoma-aho, V., \& Canel, M. J. (2016). Public Sector Reputation Overview. In C. E. Carroll, The Sage Handbook of Public Relations (2 ed., pp. 597600). London: Sage Publications, Inc.

MASTEL. (2017, February 13). Hasil Survey Mastel Tentang Wabah Hoax Nasional. Retrieved from http:// mastel.id/infografis-hasil-surveymastel-tentang-wabah-hoaxnasional/

Mediaswati, R., \& Sidik, F. (2013). Analisa Penerapan Aplikasi Pelaporan Kepegawaian Berbasis Web Pada Badan Kepegawaian Daerah Kabupaten Cilacap. Jurnal Kebijakan \& Administrasi Publik, 17(1), 4-14.

Mergel, I. (2016). Big Data in Public Affairs Education. Journal of Public Affairs Education, 22(2), 231-248.

Nisa', K. (2018, Juni). Pengaruh Sinkronisitas Media pada Hubungan antara Persepsi Nilai dan Kepuasan ter- hadap Intensi Loyalitas (Studi terhadap Perilaku Pengikut Akun Media Sosial Indonesiabaik.Id). Thesis. Jakarta, Jakarta, Indonesia: Universitas Indonesia.

Petrovici, M. A. (2013). E-Public Relations: Impact and Efficiency: A Case Study. Procedia - Social and Behavioral Sciences, 141, $79-84$.

Phillips, J. (2008). The Particular Case of Life Science. The Communication Journal, 13(5), 1-8. Retrieved from https://irfcom.ch/wp-content/ uploads/fachzeitung13.pdf

Prindle, R. (2011). A Public Relations Role in Brand Messaging. International Journal of Business and Social Science, 2(18), 32-36.

Rusfian, E., \& Nurhajati, L. (2015). Political Public Relations dalam Media Sosial: Kajian Teoritis dan Implementasinya untuk Kandidat Politik. Jakarta: UI-Press.

Schönberger, V. M., \& Cukier, K. (2013). Big Data: A Revolution That Will Transform How We Live, Work and Think. New York: Houghton Mifflin Harcourt.

Smith, R. D. (2002). Strategic Planning for Public Relations. New Jersey: Lawrence Erlbaum Associates.

Subdirectorate of Information Processing, Directorate of Information Processing and Provision, Directorate General of Public Information and Communications. (2017). Laporan Semester 1 Subdirektorat Pengolahan Informasi. Jakarta: Ministry of Communications and Information Technology.

Subiakto, H. (2014). Komunikasi Politik, Media dan Demokrasi (2 Ed.). Jakarta: Kencana Prenadamedia Grup.

Theaker, A. (2004). The Public Relations Handbook (2 Ed.). Oxfordshire: Routledge Taylor \& Francis Group.

Wahyuni, S., \& Indarwanto, B. (2008). Implementasi Digital Government Services pada Bidang Pendidikan di Pemerintah Provinsi DIY. Jurnal Kebijakan \& Administrasi Publik, 12(1) 